OOPEN ACCESS

International Journal of Advanced Economics

P-ISSN: 2707-2134, E-ISSN: 2707-2142

Volume. 2, Issue 3, P.No.39-51, October, 2020

Fair East Publishers

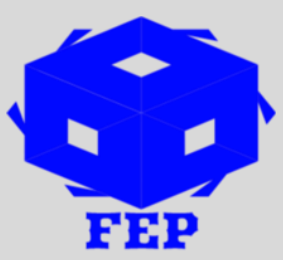

Journal Homepage: www.fepbl.com/index.php/ijae

\title{
INDUSTRIALIZATION IN TANZANIA: THE NEED FOR SOCIAL INCLUSION
}

\author{
Kitojo Wetengere
}

*Corresponding Author: Kitojo Wetengere

Corresponding Author Email: wetengerekkj1@yahoo.com

Article Received: 09-09-20 Accepted: 15-10-20

Published: 25-10-20

Licensing Details: The author retains the right to this article. The article is distributed under the terms of the Creative Commons Attribution-NonCommercial 4.0 License (http://www.creativecommons.org/licences/by-nc/4.0/) which permits non-commercial use, reproduction, and distribution of the work without further permission provided the original work is attributed as specified on the Journal open access page.

\begin{abstract}
The objective of this study was to examine industrialization in Tanzania and the need to include the disadvantaged people in the development process. This study used a documentary review methodology. The study found that although industrialization is key to economic growth, if not properly managed, it tends to marginalize the poor people. This calls for social inclusion policy measures. The study, therefore, recommends that, if industrialization is to benefit the disadvantaged, agriculture, which employs the majority of the people, should be industrialized. Further, since the benefits of industrialization may not necessarily accrue to the poor, the above need to be accompanied by conscious efforts of the government and the private sector to provide social and economic services to the disadvantaged poor.
\end{abstract}

Keywords: Industrialization; Social Inclusion; Butter \& Bread vs. Yeast \& Bread; Economic Growth vs. Economic Development

\section{INTRODUCTION}

Since independence, industrialization has been high in Tanzania's development agenda (URT, 2016). The first phase of industrialization (1961-1966), followed the colonial approach, focusing on the Import Substitution Industrialization (ISI) strategy; which was largely processing of consumer goods for elite urban consumers (ibid.). Most industries established were capital intensive, import-dependent, and foreign-owned (Ngowi, 2009).

The second phase of industrialization (1967-1975) was characterized by state ownership of means of production following the declared policy of socialism and self-reliance as enshrined in the Arusha Declaration of 1967 (URT, 2016). During this period government's role in managing the economy increased although the foreign investors supplied machinery and equipment, and the same strategy of import substitution continued to operate (ibid.).

During the 1975-1995 period, Tanzania adopted a Basic Industry Strategy (BIS) to transform 
the economy so that most of the industrial demand would be met from resources that are available within the country (URT, 2016). That means industrial goods were to meet the basic needs of the population and intermediate and capital goods were to be produced to meet domestic industrial demand (ibid.) This strategy was unsuccessful due to the global oil crisis and the government's direct control and regulation measures, which affected the ability to import intermediate inputs and capital goods thus adversely affecting manufacturing sector capabilities to compete (ibid.). During the period various programs were implemented namely: National Economic Structural Program (NESP), Structural Adjustment Program (SAP), and Economic Recovery Program (ERP I (1986) and II (1989)).

Following the persistence of the economic crisis, and unsuccessful homegrown reforms programs i.e. NESP, SAP, and ERP I and II, in the 1990s the government moved away from state-controlled to market-led industrialization exhibiting trade liberalization and privatization. During the period, many industries closed and others were forced to undertake employee retrenchment thus, adding to the number of unemployed in the economy. In 2010 on-ward, the Integrated Industrial Development Strategy was adopted, targeting among others, export-led industrialization (URT, 2016).

Challenges which faced and continue to face industrialization in Tanzania today include: unfair competition from imported products; inadequate representation of local private industrialists; the existence of mutual mistrust between holders of political power and the private sector; weak linkages between the sector and the rest of the economy; inadequate skills and capabilities to utilize the diverse natural resource base of the country (URT, 2016). Other challenges include: lack of access to finance, modern technologies, and technical knowhow; unstable and unreliable supply of water and energy; underdeveloped transport infrastructure; and weak incentives for the private and public sectors to prioritize $R \& D$ activities (URT, 2016).

Besides, another big challenge since independence to date is to attain inclusive growth that ensures equity in society (URT, 2016). Non-inclusive growth manifests itself in aspects, such as increasing unemployment, high and pervasive rural poverty, and increasing income inequalities during high economic growth (ibid.). Promoting growth with equity requires a holistic sustainable human development policy framework that is pro-people, pro-jobs, and pro-environment (ibid.).

Responding to the above challenges, the government prepared the Tanzania Development Vision (TDV) 2025 (URT, 1999). The Vision aspires to have Tanzania transformed into a middle income and semi-industrialized nation by 2025, characterized by high quality and sustainable livelihoods; peace, stability, and unity; good governance and the rule of law; an educated and learning society; and a strong and competitive economy (URT, 1999; URT, 2016). These objectives not only deal with economic issues but also social issues like education, health, the environment, and increasing involvement of the people for their development (URT, 1999). The thrust of these objectives is to attain a sustainable development of the people (ibid.).

The attainment of the vision 2025 would be made possible through the transformation of the Tanzanian economy from " $a$ weather and market-dependent agricultural economy to a selfsustaining semi-industrialized economy" (URT, 1999). This shift in focus was essential for the ailing (poorly) industrial sector in Tanzania (URT, 2016). It was anticipated that industrialization would contribute to higher economic growth, increased average per capita income, and to eradicate absolute poverty (ibid.). 
It is based on the above that industrialization is at the top of the development agenda in Tanzania today. However, it has been noted that industrialization, if left alone, may marginalize the poor and deter efforts to alleviate absolute poverty. This necessarily calls for increased involvement of the people to contribute to their development (URT, 1999) i.e. social inclusion.

\section{The objective of the Paper}

This paper was intended to examine industrialization in Tanzania to stimulate economic growth for the benefits of poor people. Specifically, the study attempted to:

(i). Investigate industrialization as a driver of Tanzania's economic growth; and

(ii). Examine if industrialization in Tanzania is socially inclusive.

\section{METHODS AND MATERIALS}

This paper used a documentary review methodology. This method is a technique used to classify, explore, and interpret written documents from various sources. Further, the documentary analysis deals with documents, which are reliable and cost-effective, and ensures that the information has a high degree of accuracy, authenticity, credibility, and representativeness, leading to valid findings and conclusions based on the study's objectives. The information for the study was obtained from journal articles, proceedings, magazines, websites, and unpublished literature. The methodology is suitable since the relations between industrialization and inclusive development are found in the mentioned sources.

\section{LITERATURE REVIEW}

\section{Definition of Terms:}

'Industrialization' is a generic name for a set of economic and social processes related to the discovery of more efficient ways for the creation of value (Simandan, 2009). These more efficient ways are lumped together under the label 'industry' (ibid.). Industrialization is a process, not an event. A process is an emergent property of a system (country or region) resulting from a collection of events that share some similarities and that unfold over a slower timescale than that of its component events (ibid.).

If one entrepreneur opens an industrial plant in an otherwise agrarian region, that singular event cannot be labeled as industrialization (Simandan, 2009). If a collection of events of this same kind achieves sufficient significance for the local economy, we can speak of a process of industrialization changing the face of that regional economy (ibid.).

Globally, the industry is broadly defined to cover mining and quarrying; manufacturing; electricity, gas, steam, and air conditioning supply; water supply, sewerage, waste management, and remediation activities, and construction (URT, 2016).

Within the industry, manufacturing is identified as the leader of the industrialization process for several justifications (UNIDO, 2012; URT, 2016). Historically, the sector has been an important driving force to economic development; has been the most knowledge-intensive sector of the economy and recipient of technological progress; exhibits higher productivity and scope for innovation; and that competitiveness of manufacturing is one of the basic determinants of long-run sustainable growth (URT, 2016).

The World Bank Group defines social inclusion or inclusive development as: the process of improving the terms for individuals and groups to take part in society and improving the ability, opportunity, and dignity of those disadvantaged based on their identity to take part in society (https://www.worldbank.org/en/topic/social-inclusion). 


\section{Why Industrialization Matters?}

In his book, the internationally acclaimed Cambridge economist Ha-Joon Chang devotes one full section to the importance of manufacturing for economic growth (Chang, 2007 cited by UNIDO, 2012). Chang claims:

"History has repeatedly shown that the single most important thing that distinguishes rich countries from poor ones is basically their higher capabilities: manufacturing, where productivity is generally higher, and, most importantly, where productivity tends to (although does not always) grow faster than in agriculture and services" (Chang, 2007 cited by UNIDO, 2012).

Experience has shown that most countries, which managed to break the vicious cycle of poverty, are the industrialized countries (UNIDO, 2012). Evidence indicates that industrialization is linked to economic growth; play a catalytic role in transforming the economic structure of agrarian societies (ibid.); and has spillover effects on the mass population in various ways:

\section{Job Creation}

As the emergence of new and expansion of the existing manufacturing industries and related economic activities produce more outputs, their internal requirement for people gradually increases (UNIDO, 2012). Consequently, they bring in more people to work, thus increasing the rate of employment. The employees with different levels of education and skills will then earn income and in that way, income poverty will be reduced. If the emergence of the industries benefits more of the semi and non-skilled workers, it would increase income and reduce income inequality within the community (Wetengere, 2019).

Caution: While this may seem to be true, experience has shown that for it to happen it would depend on the type of industries established (whether capital or labour intensive); the location of the industries (whether located in the urban/cities or rural areas) (URT, 2011); the qualification of the employees (whether the recruitment requires highly educated or uneducated, highly skilled or semi/non-skilled); and the existence of forward and backward linkage of the industries and other sectors (whether the industries foster linkage across the sectors or not) (URT, 2011).

\section{Generation of Technology, Skills, and Competitiveness}

This is key and one of the most important contributions of industrialization. Manufacturing industries generate externalities in technology development, skill creation, and learning that are crucial for competitiveness (URT, 2016; UNIDO, 2012). For instance, manufacturing is the main vehicle for technology development and innovation, representing the hub of technological progress (UNIDO, 2012). Industry uses technology in many forms and at different levels to increase returns to investments by shifting from low to high productivity activities (ibid.). Manufacturing also offers great potential for informal innovation activities such as ad hoc incremental improvements in products and processes (ibid.).

Caution: The applicability and relevance of the technology to the local environment is key to its success. In many cases, most of the technology generated by industries has been less adopted by locals or is not applicable and hence had an insignificant contribution to the locals.

\section{Increasing the Availability of Goods and Services}

The emergence of new and expansion of industries and related business entities produces more goods and services and of different qualities. This means more goods and services would be available for consumption for the majority of the population. This widens the choice and as a result, improves the standard of living; reduces inequality and poverty (Wetengere, 2019). 
Moreover, excess goods and services produced are exported to earn foreign currency, which enables the country to buy what they do not produce like fuel, technology, medicines for humans and livestock, and insecticides for agriculture (ibid). Manufacturing accounts for the bulk of world exports (78 percent in 2010) and is less exposed to external shocks, price fluctuations, climatic conditions, and unfair competition policies (UNIDO, 2012).

The price of manufactured goods tends to be more stable than that of commodities (ibid). Unfair competition policies have distorted prices around the world, limiting the potential for export growth in some commodities.

Caution: The extent to which an increase of goods and services will have an impact on the welfare of the people will depend on the availability of goods and services, quality of the products, their prices, and people's taste in favour of the goods and services produced (Wetengere, 2019). In a country where they produce what they do not consume and consume what they do not produce and most people, particularly, the elite and the well-to-do prefer the consumption of imported goods and services to local goods and services, it is unlikely that the locally produced goods and services would have any significant benefit to the community's wellbeing (ibid.).

Similarly, in a situation where we produce what we do not consume and consume what we do not produce, it is unlikely that the earned foreign currency would be used wisely. The highly valued foreign currency is likely to be used wastefully on what could be produced locally and on necessities.

\section{Increasing Government Revenue}

The emergence of new and expansion of industries and related economic activities increases government revenue (Wetengere, 2019). An increase in government revenue enables the government to provide more social and economic services like water, education, health, housing, roads, electricity, roads, and more opportunities for the majority less fortunate (ibid.). This would be beneficial particularly to the majority poor who cannot pay for the above public goods. Furthermore, the revenue collected would enable the government to establish various development projects. Both attempts would reduce poverty and inequality within the community (ibid.).

Caution: The extent to which this will be realized will depend on whether the revenue is collected. In other words, it depends on the rate of tax evasion, tax exemption, and tax base. Besides, it will depend on if the collected revenue is used for the poor or not. In a country where corruption is alarming, it is unlikely that more revenue will be collected and the revenue collected would be used for the benefit of the poor population.

\section{Increasing Income Due to Inter-Linkage of Sectors}

The employees in the newly emerged and expanded industries (manufacturing sector) and other emerged business and service sectors would demand more goods and services produced by other sectors (Wetengere, 2019). For instance, more food and raw materials would be demanded by the manufacturing and service sectors. This would stimulate the agriculture sector to produce more goods and services to meet the emerged demand (ibid.). However, to be able to do that, the agriculture sector would need more inputs like insecticides, seeds, pesticides, fertilizers, machines, and other tools from the manufacturing sector (ibid.).

On the other hand, the service sector would also be required to provide the necessary services like transport, extension services, banking, insurance, health, and education to the agriculture and the manufacturing sectors (UNIDO, 2012; Wetengere, 2019). Such interlinkages of sectors would be beneficial to the employees (in terms of increasing income) of all sectors and 
the economy as a whole (Wetengere, 2019).

Caution: This would happen if and only if the production content of the manufacturing sector is largely dependent on the locally available raw materials and the major consumption preference of the urban population is for the locally made products. In a country where the local production content is highly dependent on imported raw materials and the consumption of the majority population is in favor of imported goods and services, it is unlikely that this benefit will be realized.

\section{The Negative Aspects of Industrialization/Economic Growth}

Economic growth engineered by industrialization if not planned properly, may have negative effects on the economy, that is: it promises more goods and services in the future at the expense of consuming less today i.e. $\mathrm{Y}=\mathrm{C}($ less $)+\mathrm{S}($ more $)(\mathrm{I})$. That means, present consumption need to be sacrificed to generate more saving and investment now for future production; it leads to depletion or deterioration of resources like loss of land fertility, depletion of fisheries resources, capital depreciation, deforestation, and environmental deterioration and pollution due to high motivation to produce more; and less leisure today at the expense of hard-working and loss of energy.

Other negative effects of industrialization include: it may lead to slums, pollution, crimes, and theft; it may lead to poverty, unemployment, and income inequality especially when industries are capital intensive and are located in few areas; and while benefits are accrued to the producers/owners of the industries, the cost is incurred by the whole community in terms of pollutions, noise, slums, diseases, and traffic congestion/jams.

\section{Factors Driving the Growth of Tanzania's Economy}

Over the past thirteen years (2005 - 2018), the economy of Tanzania expanded at an annualized rate of approximately $7 \%$ and is likely to grow at the same rate annually for the next years (JMT, 2018). This growth stability is explained by three factors. First, four crucial sectors that have expanded rapidly in the 2019-20 years (Budget Speech 2020/21 Financial Year). These sectors include: mining (17.7\%), Construction (14.8\%), the Arts and Entertainment (11.2\%), and Transport and Logistics (8.7\%) (ibid.).

Other fast-growing sectors, which have been expanding rapidly since 2005 include: professional undertakings, science and vocational activities and information and communication (Budget Speech 2019/20 Financial Year); manufacturing, retail trade, financial, and tourism sectors (URT, 2011; AfDB, 2013). These sectors together contribute almost $60 \%$ of the growth in Gross Domestic Product (GDP) since 2008 (World Bank, 2013; JMT, 2018). Agriculture, which commanded a 28.2\% share of the overall economy in 2018, grew by 5.4\% (Budget Speech, 2020/21 Financial Year).

Second, economic growth has been fueled by a steady increase in domestic demand, resulting from the rapid rate of population growth (World Bank, 2013). Tanzania's current population growth rate is constant at $2.7 \%$ per year and is doubling every 25 years (ibid.). Furthermore, lower food prices (inflation standing below two digits) and prudent monetary policy have been the main contributors to this development (ibid.). Third, Tanzania's economic performance has been fairly independent of net external trade, which is explained by the country's relative isolation from the world markets (ibid.). So, Tanzania's economic growth is not very much affected by global changes.

The average annual growth rate of GDP of $7 \%$ so far attained in the past decade, while impressive, is lower than the targeted rate of $8-12 \%$ deemed necessary to eradicate absolute poverty and to realize the projected per capita nominal income of US\$ 3,000 by 2025 (URT, 
2016). A GDP growth rate of $8 \%$ and above can only be achieved with a shift to higher valueadded production processes than is currently the case, where production and trade of raw primary products are predominant (see figure 1).

This requirement has prompted the government to emphasize four driving factors namely: industrialization; openness to regional and global trade than previously; infrastructure development and technology and innovation (see figure 1). The former three drivers are required to cause the "jump" that is a shift to the production process that add value to raw primary products (URT, 2016). While technology and innovation are vital at all stages, but it is an important requirement to foster steady growth (ibid.).

In other words, the requirement would enable Tanzania to attain a Middle-Income Country (MIC) status by 2025; which means, the economy must shift to a higher Value and Faster Growth Path (see figure 1; URT, 2016).

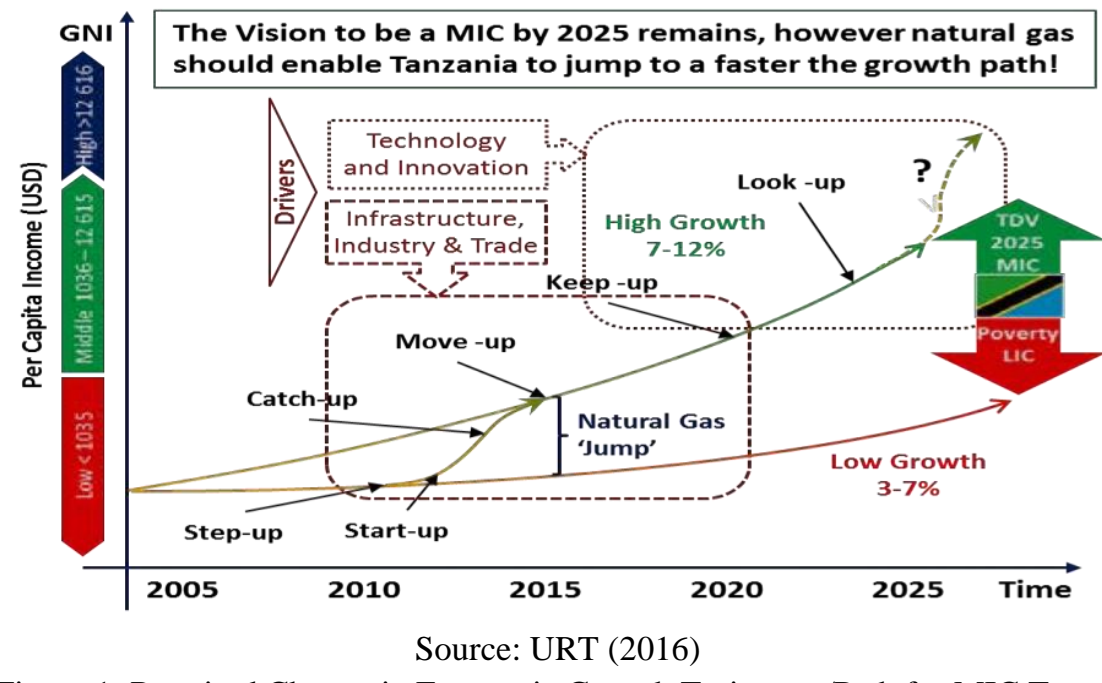

Figure 1: Required Change in Economic Growth Trajectory/Path for MIC Target Key: MIC= Middle Income Country; LIC= Low Income Country

The drivers and their role to "cause a jump" are hereby briefly analyzed:

Industrialization is vital to enhance rapid economic growth as it generates jobs; produces goods and services for home consumption as well as for export to earn the highly needed foreign currency; generate revenue which enables the government to provide necessary services; generates technology, skills, and competitiveness, and fosters forward and forward linkages.

International trade open-up/widens markets for local produce and therefore enhance home production; earns revenue to the government and the highly needed foreign currency; generate job; enables the country to acquire goods and service which it does not produce through imports; and finally, enhances competition by opening up products from outside.

The development of infrastructure is key to industrialization and economic growth. No country would attain industrialization and rapid economic growth without developing modern and efficient infrastructure. The infrastructure needed are transport i.e. roads, railways, air, and water transport; generation of adequate, affordable, and reliable energy (Hydro-power, solar, gas, fuel, coal, and wind); and communication and information. Modern and efficient infrastructure tends to widen markets within and outside the country; lower production cost; enable timely delivery of people and goods; and promote trade, investment, and tourism.

Modern technology and innovation are the key factors in improving efficiency and 
competition. As the third president of Tanzania Hon. Mkapa said, "the $21^{\text {st }}$ century is characterized by competition and if we are to be active participants in the global development we must among other things embrace advanced technology" (URT, 1999). Modern technology tends to improve efficiency and reduce costs per unit over time, making the production process more profitable and competitive (ibid.).

Another driver not mentioned in figure 1, is the development of a competent labour force (URT, 1999). Tanzania envisages to be a nation with high quality of education at all levels; a nation, which produces the quantity and quality of educated people sufficiently equipped with the requisite knowledge to solve the society's problems, meet the challenges of development and attain competitiveness at regional and global levels (ibid.). Despite that good intention and efforts made so far, there are still shortages in the fields of science and technology, industrial and gas.

Improvement of the above drivers, would require concerted efforts to build and reorganize domestic productive capacities and at the same time ensuring a conducive environment for doing business and investment (URT, 2016). The envisaged industrialization has to be based, among other factors, on the country's comparative advantages and on upgrading innovativeness to integrate and deepen into regional and global value chains and pursue competitive industrialization (ibid.).

It is believed that the industrial economy would, among others, foster economic growth, reduce economic vulnerability, enhancing forward and backward linkages between and within sectors, ensuring positive spill-over effects of skills development and technology innovation, creation of decent jobs, and ensuring environmental sustainability (URT, 2016).

During the implementation of the vision, encouraging results have been achieved. The per capita Gross Domestic Product (GDP) has increased to US\$ 1,126 or Tshs. 2,577,967 (2019), from US\$ 749.3 or Tshs. 1,700,000 (2010) (Tanzania Budget Speech 2020/21 Financial Year). This implies that Tanzania has attained a low middle-income country status (ibid.). Furthermore, Tanzania's economy grew by on average $7 \%$, being the second fastest in East Africa after that of Rwanda (8.6\%) (ibid.). Also, it has become the $10^{\text {th }}$ biggest economy in Africa and the $2^{\text {nd }}$ biggest in East Africa.

Despite such performance, non-inclusive growth manifests itself in several aspects, such as increasing unemployment, high and pervasive rural poverty, and increasing income inequalities during high economic growth (URT, 2016). This is in line with widespread complaints among common citizens that they have not felt the benefits of economic growth. This calls for inclusive growth, which will manifest itself in people's life.

Besides, the industrial growth rate, particularly that of the manufacturing sector, ranged at 6 $8 \%$ (URT, 2016). This rate is too low to champion the growth of the economy as stipulated in the TDV 2025. Also, the sector contributed about 7\% of the GDP (ibid.). Size-wise, out of 49,247 industries established, about 47,921 (97\%) were small-scale industries employing less than 10 people per industry (ibid.). That means, the manufacturing sector did no have a significant impact on employment as was expected.

\section{Social Inclusion or Inclusive Development}

Despite the benefits of the industrial economy, experience has shown that if not properly managed it tends to sideline the poor, particularly those living in the rural areas (URT, 2016; Wetengere, 2019). According to NBS (2014), 4.2 million Tanzanians live in extreme poverty. The extreme poor are often caught in persistent poverty traps and cannot take advantage of the emerging opportunities created by growth and structural transformation (Morisset, 2013). This 
is because most industries were located in urban areas, employing fewer people and most poor did not have access to services such as energy, healthy, loan, education, markets, technology, and means of transport, communication, and information. That means conscious efforts need to be done to ensure that growth-led industrialization is socially inclusive (URT, 2016; Wetengere, 2019).

\section{Economic Growth Versus Economic Development}

One of the challenging issues in economics is the relationship between economic growth and economic development (Todaro, 1977). While economic growth is a quantitative increase in the gross domestic product of a country or capability of the economy to produce a greater output of goods and services; economic development refers to a qualitative structural change in an economy (Simandan, 2009) or improving the wellbeing of the poor. Still, while economic growth is a pre-requisite for development, it does not guarantee it.

The problem - as some Third World Countries (LDCs) have experienced - is that they have attained high economic growth without necessarily attaining massive economic development (Simandan, 2009). In Tanzania for instance, for the past 13 years, the economy has grown by on average $7 \%$ but without significantly improving the wellbeing of the common man (URT, 2016). The late Mwalimu Nyerere (1974) explains why this can happen and he says, "if the growth of things like buildings, roads, airplanes, railways, irrigation schemes or goods and services, do not involve the people to produce them, they will not have an impact on their well being".

The lesson learned from this brief analysis of economic growth vs. economic development is whether industrialization is beneficial or not critically depends on what kind of industrialization one is speaking about (ibid.).

\section{Conceptualization of Butter \& Bread versus Yeast \& Bread $^{1}$}

To ascertain whether certain policy actions would have a positive impact on the well-being of the people (social inclusive) or not, we need to understand the relation between butter \& bread versus yeast $\&$ bread. To begin with, butter is not part of bread - their making is independent of each other. In other words, butter is not involved in making bread - it is just pasted on bread after the bread has been made to soften it and change the taste of the bread in favour of the consumer.

On the other hand, yeast is part of bread - it is an inevitable ingredient in making bread. It is actually what makes the whole bread grow, without it do not expect to get bread, instead you will for sure get stiff porridge of wheat or what is called in Kiswahili "ugali wa ngano".

Having that analysis in mind, it can now be applied to examine whether industrialization and agriculture would benefit the local economy or not.

\section{(i). Industrialization should be embedded in the local economy}

It was observed earlier in this paper that some of the main challenges facing industrialization were that most industries established were: located in few urban areas to serve elites consumers; import-dependent; capital intensive; export-led, and had weak linkages with the rest of the economy (URT, 2016). That means industries alienated the majority of poor particularly those living in the rural areas. So, industrialization witnessed economic growth without inclusive development i.e. having an impact on the local people.

In such a situation, industrialization was not organically embedded in the local economy. That is, industrial plants increased quantitatively (economic growth), without any qualitative impact

${ }^{1}$ Adopted from Simandan (2009) and modified to suit Tanzanian's situation. 
(economic development) on the local people. Such industrialization played the role of butter \& bread i.e. it did not have a role to play to the wellbeing of the local people. In other words, the growth of the economy engineered by industrialization was independent of the improvement of the wellbeing of the people.

If industrialization is to have an impact on the wellbeing of the majority poor, it has to comprise of industries which are labour intensive i.e. which employ many local people; they come with modern technology, skills, and competitiveness; they add value to agriculture (crops, forest, fisheries, and livestock) products; they produce goods and services for home consumption as well as for export to earn hard currency; they generate revenue; they produce equipment needed for the development of other local industries in the economy; and they foster forward and backward linkages. In that way, industrialization would have a massive impact on the local economy.

Such industries play the more ambitious role of the yeast that makes the whole bread to grow i.e. industrialization is embedded in the local economy, which makes the national economy to grow. Since the local people actively participate in making the economy grow, it follows that, as the economy grows, the well being of the local people grows as well!

\section{(ii). Agriculture should be industrialized and be embedded with other factors driving the growth of Tanzania's economy}

The trend of Tanzania's economic growth has been driven by some capital-intensive sectors whose activities are predominantly located in cities and a small number of growth centers (URT, 2011; Morisset, 2013). These sectors together contributed approximately $60 \%$ of GDP growth (World Bank, 2013; URT, 2016: Tanzania Budget Speech 2019/20).

However, the main characteristics of these sectors are that they are unable to absorb a good number of job seekers - the majority of who are less educated in the rural and urban areas (URT, 2011). Neither do the fast-growing sectors provide markets for the agriculture produce, creating a weak linkage with the agricultural sector (ibid.). These results explain why the benefits of economic growth have been skewed against the agriculture sector (ibid.). That means the agriculture sector has been sidelined by economic growth.

The agriculture sector is the mainstay of more than $80 \%$ of the rural population (JMT, 2018) and employs $67 \%$ of the labour force. However, a notable concern is the slow growth of the agriculture sector, which has averaged $4.4 \%$ over the 2000 - 2008 period (Pauw and Thurlow, 2010; Osberg and Bandara, 2012). In 2016 it grew by $3.6 \%$ and increased slightly to $5.4 \%$ in 2018 (JMT, 2018). This rate of growth is not higher enough to reduce poverty for the majority of the rural poor (Wetengere, 2019).

The National Strategy for Growth and Reduction of Poverty (NSGRP) stated that if poverty was to be reduced by $50 \%$ by 2010 , the agricultural sector should have grown at a rate of $10 \%$ for a period of at least 5 years (2006 - 2010). This was not realized as the year 2010 was reached, which was the end of NSGRP implementation (Mashindano, 2009). Furthermore, the sector's share of GDP has also declined from 31.3\% in 2000 to 27.2 in 2007 (World Bank, 2013a), but increased slightly to $28.2 \%$ of GDP in 2019.

Agriculture is one and/or the only sector which fulfills the necessary requirements for inclusive development/social inclusion. First, it has wider benefits in terms of the number of people working in/dealing with the sector. Second, its benefits directly improve the well-being of the poor. Third, there is a high possibility that its implementation and benefits are acquired in a short period. It is on the same line that, Makhtar Diop, the World Bank Vice President for Africa, said that "there is global evidence showing that productivity improvements in 
agriculture can have a poverty impact close to 3 times that of other sectors of society" (World Bank, 2013a).

If agriculture is to contribute significantly to economic growth and poverty alleviation, it should play a more ambitious role of the yeast that makes the whole bread grow (Simandan, 2009). That means, the agriculture sector, which employs the majority of people, should be one of the fast-growing sectors (10\% and above) and the main contributor to Tanzania's economic growth.

For that to happen, agriculture needs to be integrated with factors, which make the economy grow. That means, to establish industries, which add the value of agriculture (crops, fisheries, and livestock) products, in other words, to industrialize agriculture. Other factors include: employ modern technology and innovation to enhance productivity in the agriculture sector; construction of modern infrastructure i.e. transport, energy, and information, and communication to connect agriculture producing areas with the markets; agriculture should be the main supplier of raw material for the industrial sector and food for the urban dwellers, and in turn, the consumer of other sectors' produce; and should employ competent labour force.

\section{Provision of the Necessities of Life ${ }^{2}$}

Since the benefits of industrialization may not "trickle-down" to the mass population, as it has been the case in Tanzania, conscious efforts need to be done to reach the poor (Wetengere, 2019). That is why the government and/or public-private partnership need to improve access by the poor to social and economic services. Services important to the poor include: education, health, water, housing, micro-credit schemes, markets; telecommunications (mobile phones), means of transport, and electricity. The government use revenue collected from economic activities to provide free education from primary to secondary schools and loans for students of high learning institutions; health insurance services for all; affordable prices for electricity and water services; and reduced interest for the bank loan.

Some studies have shown that access to secondary and girls' education is important for poor households given the growing skill bias in non-agricultural employment - "falling fertility rates and rising female labour market participation is essential in poverty alleviation. Sutter (2013) made it clear that "there is no surer ticket out of poverty than a solid education". In the same vein, Wetengere (2013) found that the use of mobile phones provided timely and accurate market information, widened market options, improved negotiation power, and maintained freshness of the products. Also, mobile phones reduced losses and saved time and money, all of which increased farmer's income considerably (ibid.). It is on this ground that farmers regard mobile phone as a tool like other agricultural tools (ibid.).

\section{Provision of Safety nets ${ }^{3}$}

Since most of the extreme poor live in the rural areas and cannot take advantage of the emerging opportunities created by growth and structural transformation, the government introduced Safety Net Programs (SNP) as a mean to reduce insecurity and guaranteeing a minimum level of consumption (Morisset, 2013; Subbarao et al., 1997). SNP (TASAF) has started operating in Tanzania since 2010 and has contributed to reduce poverty and inequality and now needs to be expanded (Wetengere and Sabuni, 2015).

Safety net transfers include: cash transfers; food-based programs like food stamps and supplementary feeding programs, vouchers, and coupons; in-kind transfers like school supplies and uniforms, conditional cash transfers, price subsidies for food, electricity, or

${ }^{2}$ Cited from Wetengere (2019).

${ }^{3}$ Cited from Wetengere (2019). 
public transport, public works, and fee waivers and exemptions for health care, schooling, and utilities.

\section{CONCLUSION AND RECOMMENDATION}

The Tanzania Development Vision (TDV) 2025 focused on industrialization as one of the key drivers to attain a semi-industrialized economy. While industrialization has a massive contribution to economic growth i.e. growth of things, it does not necessarily always guarantee economic development i.e. improving the well-being of the majority poor. This means, if industrialization is not well managed, it may lead to an adverse situation.

It is because of the above that this paper put forward the following suggestions: First, the industries established should play a more important role of yeast, which makes bread to grow. That means establish industries, which are labour intensive; produces goods and services for home consumption and export; generates revenue, and foster linkages.

Second, agriculture, which is the mainstay of the majority poor, should be industrialized and embedded with other factors driving Tanzania's economic growth. Third, the government should provide necessary services such as education, water, health, housing, micro-credit schemes, infrastructure (transport, energy, and communication) to the poor. Finally, the government should provide Safety Net Programs (SNP) to reduce insecurity and guarantee a minimum level of consumption for the poor.

\section{References}

African Development Bank-AfDB, (2013). Tanzania Economic Outlook. http://www.afdb.org/en/countries/east-africa/tanzania/tanzania-economic-outlook/ (Retrieved on $28^{\text {th }}$ January 2020).

Jamhuri ya Muungano wa Tanzania (JMT), (2018). Hali ya Uchumi wa Taifa na Utekelezaji wa Bajeti ya Serikali. Taarifa ya Wizara ya Fedha na Mipango kwa Vyombo vya Habari 30 Desemba, 2018 - Dar es Salaam.

Mashindano, O. (2009). Growth and Poverty Reduction in Tanzania: Why such a Mismatch? The Economic and Social Research Foundation (ESRF) Policy Brief Series No.1 2009. http://www.esrf.or.tz/docs/growth-poverty\%20.PDF (Retrieved on $5^{\text {th }}$ March 2020).

Morisset, J. (2013). Tanzania economic update: raising the game - can Tanzania eradicate extreme poverty? Tanzania economic update; issue no. 4. Washington, DC: World Bank Group. http://documents.worldbank.org/curated/en/2013/12/18620924/tanzaniaeconomic-update-raising-game-can-tanzania-eradicate-extreme-poverty (Retrieved on $25^{\text {th }}$ November 2019).

National Bureau of Statistics (NBS), (2014). Household Budget Survey (HBS) 2011/12, Dar es Salaam. Pp. 160.

Ngowi, H. P., (2009). Economic development and change in Tanzania since Independence: The political leadership factor. African Journal of Political Science and International Relations Vol. 3 (4), pp. 259-267 Available online at https://academicjournals.org/journal/AJPSIR/article-full-text-pdf/08ECB177561.

Nyerere, J. K. (1974). Binadamu na Maendeleo. Oxford University Press. Dar es Salaam. Kurasa 138.

Osberg, L., \& Bandara, A. (2012). 'Why Poverty Remains High in Tanzania: And What to Do About It?' Special Paper 12/3, Dar es Salaam, REPOA.

Pauw, K., \& Thurlow, J. (2010). Agricultural Growth, Poverty, and Nutrition in Tanzania. International Food Policy Research Institute (IFPRI) Discussion Paper 00947. PP. 40. 
Simandan, D. (2009). Industrialization, In R., Kitchin \& N., Thrift, (Eds.), International Encyclopedia of Human Geography, Oxford: Elsevier, volume 5, pp. 419 - 425. https://www.researchgate.net/publication/305725435 (Retrieved on $25^{\text {th }}$ November 2019).

Subbarao, K., Bonnerjee, A., Braithwaite, J., Carvalho, S., Ezemenari, K., Graham, C., Thompson, A. (1997). Safety Net Programs and Poverty Reduction Lessons from Cross-Country Experience. The International Bank for Reconstruction and Development/THE WORLD BANK, N.W. Washington, D.C.

Sutter, J. D. (2013). 7 Ways to Narrow the Rich-poor Gap. http://edition.cnn.com/2013/10/29/opinion/sutter-solutions-income-inequality/ (Retrieved on $24^{\text {th }}$ May 2020).

Todaro, M., P. (1977). Economic for a Developing World. Longman Group Limited, London, UK. pp 444.

United Republic of Tanzania (URT), (1999). The Tanzania Development Vision (TDV) 2025. The Tanzania Planning Commission.

United Republic of Tanzania - URT (2011). Country report on Millenium Development Goals 2010. Dar es Salaam, Tanzania. Pp. 66.

United Republic of Tanzania (URT), (2016). National Five Year Development Plan 2016/17 2020/21: "Nurturing Industrialization for Economic Transformation and Human Development" Ministry of Finance And Planning.

United Nations Industrial Development Organization (UNIDO), (2012). Tanzania Competitiveness Report 2012.

Wetengere, K., (2019). Is Tanzania's Economic Growth pro-poor? International Journal of Advanced Economics, 1(1), 1-17. www.fepbl.com/index.php/ijae.

Wetengere K., \& Sabuni D., (2015). Efficacy of Safety Net Programmes in Reducing Poverty in Tanzania: Lessons Learnt from Bangladesh. AEBR 2015, 2(1),1-10 http://manuscript.sciknow.org/uploads/aebr/pub/aebr_1404181568.pdf.

Wetengere K. (2013). Marketing of Agricultural Perishable Products Using Mobile Phones for Improving Rural Income. A Case of Bigwa Ward, Morogoro Region, Tanzania. IRJM, 1(1), 1-11. http://manuscript.sciknow.org/uploads/irjm/pub/irjm_1367550461.pdf

World Bank, (2013). Tanzania Economic Up-todates: Opening the Gates: How the port of Dar es Salaam can Transform Tanzania; issue no. 3. http://wwwwds.worldbank.org/external/default/WDSContentServer/WDSP/IB/2013/05/16/00044 2464_20130516111239/Rendered/PDF/777290WP0P13340onomic0Update0Report.p df (Retrieved on 24 $4^{\text {th }}$ June 2020).

World Bank, (2013a). Tanzania economic update: raising the game - can Tanzania eradicate extreme poverty? Tanzania economic up-date; issue no. 4. Washington, DC: World Bank Group. http://documents.worldbank.org/curated/en/2013/12/18620924/tanzaniaeconomic-update-raising-game-can-tanzania-eradicate-extreme-poverty (Retrieved on $26^{\text {th }}$ November 2019). 